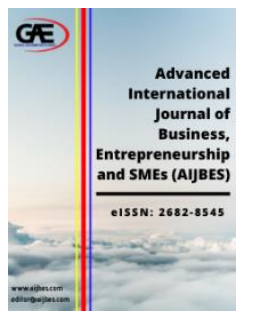

\author{
ADVANCED INTERNATIONAL JOURNAL OF \\ BUSINESS, ENTREPRENEURSHIP AND SMES \\ (AIJBES) \\ www.aijbes.com
}

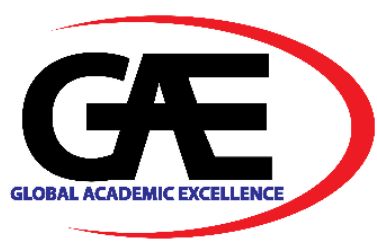

\title{
FACEBOOK ADVERTISING AND ONLINE PURCHASING DECISIONS: AN ANALYSIS OF THE USES AND GRATIFICATIONS THEORY
}

\author{
Pragash Muthu Rajan ${ }^{1 *}$, Fong Mi Lyn ${ }^{2}, \mathrm{Ng}$ Siew Mun ${ }^{3}$, Kok Seow Sian ${ }^{4}$, Liew Shen $\mathrm{Yi}^{5}$ \\ 1 Department of Advertising, Universiti Tunku Abdul Rahman, Perak, Malaysia \\ Email: pragashm@utar.edu.my \\ 2 Department of Advertising, Universiti Tunku Abdul Rahman, Perak, Malaysia \\ Email: fmlyn77@gmail.com \\ 3 Department of Advertising, Universiti Tunku Abdul Rahman, Perak, Malaysia \\ Email: estherngsiewmun@gmail.com \\ 4 Department of Advertising, Universiti Tunku Abdul Rahman, Perak, Malaysia \\ Email: serenekss03@gmail.com \\ 5 Department of Advertising, Universiti Tunku Abdul Rahman, Perak, Malaysia \\ Email: liewshenyi98@gmail.com \\ Corresponding Author
}

\section{Article Info:}

\section{Article history:}

Received date: 22.12 .2020

Revised date: 15.01 .2021

Accepted date: 21.01.2021

Published date: 01.03.2021

\section{To cite this document:}

Pragash, M. R., Fong, M. L., Ng, S. M., Kok, S. S., \& Liew, S. Y. (2021). Facebook Advertising And Purchasing Decisions: An Analysis Of The Uses And Gratifications Theory. Advanced International Journal of Business, Entrepreneurship and SMEs, 3 (7), 10-23.

DOI: $10.35631 /$ AIJBES.37002.

\begin{abstract}
:
Nowadays, social media has provided new opportunities for online shopping that benefit both consumers and marketers. Most of the sellers who sell products or services on their personal social media platforms are facing the issue of figuring what are the aspects that could influence consumers in their decisions to purchase products or services from the sellers, especially young adults who are active in social media platform. Interpersonal utility, information seeking, entertainment, passing time, and convenience are the five factors employed in examining the influence toward student's purchasing decisions, in-line with the Uses and Gratifications Theory approach. The quantitative research method has been employed in this study. The data was collected from 309 undergraduates from a private university in Malaysia. The study revealed a strong positive correlation between all five independent variables and the dependent variables. The factor with the strongest correlation is convenience. This study would provide useful insights to Facebook's personal sellers to promote their products or services in a better way to target their potential customers effectively.
\end{abstract}




\section{Introduction}

The way consumers shop has altered and developed greatly in the past few decades. With today's information and modern communications technology, consumers can use a variety of social media and different websites to do their shopping (Nadeem et al., 2015, Zhang et al., 2017). This type of shopping mode is called online shopping (Pham et al., 2018). Driven by the local online shoppers, Malaysia has become one of the fastest growing online markets. According to Statista (2020), Malaysia's revenue in via online market is estimated to reach US $\$ 4,455 \mathrm{~m}$ in 2020 . With approximate annual growth rate of $18.0 \%$, it is projected to obtain a market volume of US $\$ 8,635 \mathrm{~m}$ by 2024 . Nevertheless, the increase in the usage of the Internet has positively influences Malaysia's online shopping trend.

Online shopping trend among Internet users in Malaysia has developed considerably over the past two decades (Soh et al., 2020). Apart from online shopping platforms such as Lazada, Shopee, Zalora, Mudah.my, and so forth; social media sites, especially Facebook has also become another popular platform for online shopping (Kawaf \& Istanbulluoglu, 2019). Many social media users started to sell products through their personal Facebook accounts. According to Lee et al. (2016), up 94\% of Facebook users find and discover new products when they scroll through their account, and $62 \%$ of them will even make a purchase of that product.

University students particularly, with the age range from 18 to 30 years old show that they are more likely to purchase from Facebook as they always have a strong Internet connection wherever they are (Farah et al., 2018). The level of their digital literacy also affects their online purchasing decisions (Kumar \& Govindarajo, 2015). However, studies conducted on online purchasing behaviour among university students are scarce, especially purchasing with personal sellers in Facebook. Therefore, it is important to identify the determinants of online purchasing decisions based on Facebook advertisements by personal sellers.

Uses and Gratifications Theory (UGT) is often use to understand the impact of social media on its users. Five most acknowledged gratifications applied in the past studies include interpersonal utility, information seeking, entertainment, passing time, and convenience (Buzeta et al., 2020; Kircaburun et al., 2020). Thus, these five factors will be employed as the independent variables in this study to investigate its impact on the online purchasing decision based on Facebook advertising.

Therefore, based on the discussion above, present study is aims to investigate the relationship between interpersonal utility, information seeking, entertainment, passing time, and convenience and purchasing decision based on Facebook advertising by personal sellers among university students. 


\section{Literature Review}

\section{Online Purchasing Decisions}

With the development of online business, the third most famous activity after web-surfing and email is online purchasing (Jamali et al, 2014). Online purchasing decisions can be defined as the consumers' readiness to buy products and services online (Meskaran et al., 2014). Purchasing decisions can be explained as how consumers purchase and discard ideas, experiences, goods or services as a means to meet the consumer's wants and needs (Kotler \& Keller, 2011). In some cases, a problem solving activity will arise when purchasing and this will provide the consumers with a chance to resolve the challenges through stages (Agosi \& Pakdeejirakul, 2013). The purchasing decision process is made up of five phases, which are problem recognition, information search, evaluation of alternatives, purchase decision, and post purchase behaviour (Qazzafi, 2019). To better understand consumer's purchasing decisions, marketers should to carry out advertising and promotional campaigns to influence consumer buying (Haider \& Shakib, 2018). This is because consumer decision serves as a powerful tool for marketers to achieve their good business (Sama, 2019). Furthermore, in the recent days, the integration of social media sites as a strategic marketing tool has delivered highly persuasive influence towards customer purchasing decisions (Zhang et al., 2016). Customers are more motivated to use social media to check on a product, the quality and the testimonials from previous buyers to help determine the trustworthiness of the product (Ahmed, 2020). Tuten and Solomon (2020) further emphasised that social media advertising plays prominent role in influencing the consumer's decision making through promotion and active interaction with the seller. Social media refers to Facebook, YouTube, Instagram, Twitter, Snapchat, WeChat, Whatsapp, Weibo (Fuchs, 2017). However, in this study, the only social media sites involve is Facebook. Therefore, any types of advertisement or promotion stuff posted by the personal sellers in their own Facebook account are considered as Facebook advertising, such as Facebook Live, Facebook Stories, videos, photos, posts, and so forth.

\section{Interpersonal Utility}

Interpersonal utility is also referred as social interaction (Whiting \& Williams, 2013), is one of the factors motivate people to use social media to communicate and interact with others. Whiting and Williams (2013) further added that by interacting with people in one's social circle and update themselves with the latest issues, users tend to spend more time in social media sites, which intuitively influence their decision to purchase online based on the social media advertisements. Liani and Rina (2020) further explained the attributes of interpersonal utility in using social media include individual's intention to take part in discussion, to support others, to develop a sense of belonging, to get more point of views from others, to meet new people, and to get help from others. Personal sellers in Facebook are usually promote their product via Facebook Live, or by posting videos or photos of the product, which enables potential buyers to interact with the seller to establish a better relationship before purchasing the product offered by the seller. This is similar to the purpose of using social media. Since interpersonal utility is proven to be a factor to motivate users to spend time in social media, its ability to influence online purchasing decisions especially in Facebook remains unanswered. Hence, it is expected that:

H1: There is a positive relationship between interpersonal utility and online purchasing decisions among university students. 


\section{Information Seeking}

Information seeking is about seek out for information or to self-educate (Whiting \& Williams, 2013), which is an important purpose for the Internet users (Hur, 2017). There are few reasons why consumers seeking information online, such as information can be obtained easier, free of charge, and fast (Liani \& Rina, 2020). Consumers believe that advertisements usually supply important information related to the product of service which makes them more willing to further research about the product of service (Bomariya \& Singh, 2011). The degree of the information value in an advertisement in relation to the product or service will greatly influence response of consumer and determine its effectiveness (Rathy \& Samy, 2015). Social media is considered as a useful tool to search for information because it is possible to reach the latest information. Furthermore, consumers who are mindful are more likely to use social media to search for the information and meant to employ it in online purchasing (Kang \& Johnson, 2015). Personal sellers in Facebook always share videos and photos about the products. They also provide more detailed information through Facebook Live, which also serves as a question and answer sessions for the product promoted. This would equip the potential buyers with sufficient information before deciding whether to buy the product. Therefore, it is crucial to determine the impact of such a way of information seeking towards online purchasing decisions. Accordingly, the study proposes that:

H2: There is a positive relationship between information seeking and online purchasing decisions among university students.

\section{Entertainment}

Entertainment is defined as pleasurable, fun, and enjoyable (Whiting \& Williams, 2013). Najmi and Ahmed (2018) observed that entertainment is an important factor which attracts the attention and engagement of customers in online purchasing. Elliott and Speck (2005) stated that a highly functional and entertainment business website will help consumer to shop easily with positive mind. It can influence visitor to stay and explore the content with enjoyable feelings which tend to increase the frequency of online purchases and loyalty. ur Rahman et al. (2018) described that consumers are motivated by two shopping motivations; utilitarian and hedonic values. Utilitarian is based on rationale while hedonic shopping is about seeking pleasure. Ulaan et al. (2016) described enjoyment as the level of satisfaction that consumers feel during online purchase; the more enjoyable the processes of purchasing, the more likely consumers will repeat-purchase. Therefore, entertainment is another important reason for consumers to purchase online. Personal sellers who promote product in Facebook often use humour to convey the message about their product, especially through Facebook Live. This could enhance potential consumers' pleasure in making online purchasing decisions. These arguments lead to the following hypothesis:

\section{H3: There is a positive relationship between entertainment and online purchasing decisions among university students.}

\section{Passing Time}

A steady and growing majority of people are using the Internet when they are bored and also as a way to occupy time as high-speed broadband Internet connection is more easily attainable (Bednarz, 2011). Pass time is correlated to how individuals kill time with tasks or other daily regimens. Thus, individuals would rather occupy their free time by learning about or reviewing advertisements displayed on the Internet (Chen et al., 2016). This leads to consumers' pass time motivation which positively influences Internet advertising as they are spending more 
Volume 3 Issue 7 (March 2021) PP. 10-23 DOI 10.35631/AIJBES.37002

time on the Internet. Besides, Sundstrom et al. (2019) argued that, when consumers are too bored, they are easily triggered by features of online shopping like easy access and free delivery. Furthermore, smartphone, which accompanies people all the times, has also created an opportunity for consumers who feel bored to use it for leisure and to kill time, anytime and anywhere (Leung, 2020), which some people choose to perform online purchasing (Sundstrom et al., 2019). Personal sellers who promote product in Facebook often post videos and photos, as well as streaming videos via Facebook Live. All these contents provided by the Facebook personal sellers enable potential consumers to pass their time anywhere. Hence, this has become an easy way to kill boredom. Thus, the study posits that:

H4: There is a positive relationship between passing time and online purchasing decisions among university students.

\section{Convenience}

Convenience is the influential element that affects online shopping (Jiang et al., 2013), which regarded as the most common factor in exciting consumers to purchase online (Kawa \& Maryniak, 2018). The convenience of shopping is the means to shop and purchase products regardless of time and location (Forsythe et al., 2006). Through online shopping, consumers can avoid crowd, reduce waiting time and it also requires less energy as consumer do not need to travel to the physical locations (Juniwati, 2014). Similarly, Aldousari et al. (2016) discovered that the main reason for consumers to purchase online is the convenience to compare multiple products at one platform, which doesn't requires physically travelling. In addition, Duarte et al. (2018) revealed that consumer prefer online purchasing due to the easy access to extensive and clear description of the products which enables the consumers to understand better about the product configuration and its appearance. Lastly, Almarashdeh et al. (2019) found that consumers considered the websites accessibility as the most fundamental factor in influencing online purchasing as they can sort the products by few options such as price range, relevance, popularity, seller's location, delivery time and etc. Since everyone has the access to Facebook via app, it becomes easier for potential consumers to browse for the product that they wish to purchase. Moreover, testimonials of previous or existing consumers can also be found under the comment section of the personal seller's Facebook account. This made the process of making purchasing decision becomes easier. Thus, the study posits that:

H5: There is a positive relationship between convenience and online purchasing decisions among university students.

\section{Underpinned Theory}

Uses and gratifications theory (UGT) is focused on audience and understand what and why consumers do with the media instead of what media do to consumer (Whiting \& Williams, 2013). This theory has been widely adopted in investigating consumers' online shopping behaviour (Huang \& Zhou, 2018). Uses and gratification theory has more related as a tool to understanding how people connect themselves with the media and technologies (Eginli \& Tas, 2018). Therefore, by applying UGT, this study pursues to deliver a more comprehensive understanding of why consumers use social media, especially Facebook to make online purchasing. Based on the above reviews on the literature, the research framework of the study is developed as shown in Figure 1. 


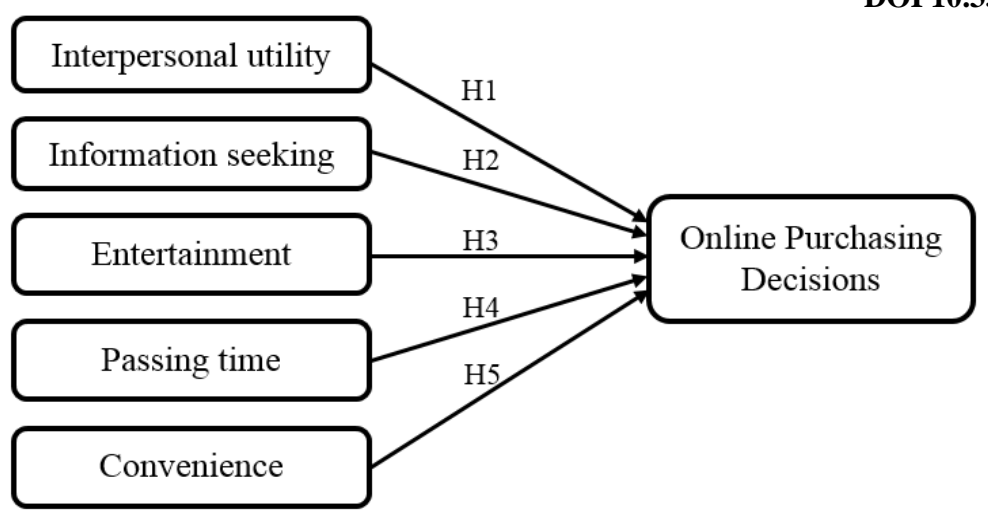

Figure 1: Research Framework

\section{Methodology}

\section{Sample and Sample Size}

The study was carried out among undergraduates from a private university in Malaysia. Quantitative research approach was applied in this study, using questionnaire as data collection tool, and convenience sampling as sampling technique. Undergraduates from a particular faculty were recruited as respondents of this study. Based on data obtained from Department of Student Affairs, the total undergraduate population of the faculty is less than 1700, as of December 2019. Thus, as per Krejcie and Morgan's (1970) sample size guideline, it requires a sample size of 310 for a population of less than 1700 (see Table 1).

Table 1: Sample Size Table

\begin{tabular}{cc}
\hline Population Size $=\mathbf{N}$ & Hypotheses \\
\hline 1500 & 306 \\
1600 & 310 \\
1700 & 313 \\
\hline
\end{tabular}

Source: Krejcie \& Morgan (1970)

\section{Data Collection Procedure}

Online questionnaires were distributed to 310 respondents. Potential respondents was first approached by the researcher through Facebook Messenger and requested to share their student ID. Once the respondent's identity is confirmed as undergraduate, the online questionnaire will be shared through the Facebook Messenger. This process was stopped once the questionnaire shared with 310 respondents. The online survey method was selected because its more inexpensive compared to the cost of traditional paper-and-pencil survey (Rudestam, 2017).

\section{The Instrument}

The questionnaire consisted a total of 35 questions in two sections. Section A consisted of five questions on the respondents' demographic information, while Section B consists of 30 questions combined for purchasing decision, interpersonal utility, information seeking, entertainment, passing time, and convenience (five items for each variable). The items of purchasing decision were extracted from a scale developed by Lautiainen (2015). The items of information seeking and passing time were derived from Chaturvedi et al.'s (2016) scale. Items of convenience were derived from Pham et al. (2018). Meanwhile, the items of both interpersonal utility and entertainment were based on Voorveld et al.'s (2018) scale. All the 
Volume 3 Issue 7 (March 2021) PP. 10-23 DOI 10.35631/AIJBES.37002

items were adopted and modified. All items in Section B were measured with a five-point Likert-type scale where 1 represents "Strongly Disagree", and 5 indicate "Strongly agree".

Table 2: Reliability Test Results

\begin{tabular}{lccc}
\hline \multicolumn{1}{c}{ Variables } & Items & Cronbach's alpha & Strength \\
\hline Purchasing decision & 5 & 0.812 & Very Good \\
Interpersonal utility & 5 & 0.803 & Very Good \\
Information seeking & 5 & 0.711 & Good \\
Passing time & 5 & 0.906 & Very Good \\
Entertainment & 5 & 0.898 & Very Good \\
Convenience & 5 & 0.888 & Very Good \\
\hline
\end{tabular}

The scales reported Cronbach's alpha value. The reliability of the scale is within the acceptable range, with Cronbach's alpha value ranged from 0.711 to 0.906 . Table 2 below indicates the reliability test results.

\section{Results and Analysis}

\section{Hypotheses Testing}

Pearson's correlation coefficient analysis was performed to identify the relationship between the independent variables and the dependent variable. Table 3 shows the results of the analysis.

Table 3: Pearson's correlation Result

\begin{tabular}{|c|c|c|c|c|c|c|c|}
\hline \multicolumn{8}{|c|}{ Correlations } \\
\hline & & IS & IU & ET & PT & $\mathrm{CV}$ & $\mathrm{PD}$ \\
\hline \multirow{4}{*}{ IS } & Pearson Correlation & 1 & $.686^{* *}$ & $.675^{* *}$ & $.633^{* *}$ & $.656^{* *}$ & $.718^{* *}$ \\
\hline & Sig. (2-tailed) & & .000 & .000 & .000 & .000 & .000 \\
\hline & $\mathrm{N}$ & 309 & 309 & 309 & 309 & 309 & 309 \\
\hline & Pearson Correlation & $.686^{* *}$ & 1 & $.818^{* *}$ & $.739^{* *}$ & $.774^{* *}$ & $.811^{* *}$ \\
\hline \multirow[t]{3}{*}{ IU } & Sig. (2-tailed) & .000 & & .000 & .000 & .000 & .000 \\
\hline & $\mathrm{N}$ & 309 & 309 & 309 & 309 & 309 & 309 \\
\hline & Pearson Correlation & $.675^{* * *}$ & $.818^{* *}$ & 1 & $.781^{* *}$ & $.817^{* *}$ & $.809^{* *}$ \\
\hline \multirow[t]{3}{*}{ ET } & Sig. (2-tailed) & .000 & .000 & & .000 & .000 & .000 \\
\hline & $\mathrm{N}$ & 309 & 309 & 309 & 309 & 309 & 309 \\
\hline & Pearson Correlation & $.633^{* *}$ & $.739^{* *}$ & $.781^{* *}$ & 1 & $.749^{* *}$ & $.761^{* *}$ \\
\hline \multirow[t]{3}{*}{ PT } & Sig. (2-tailed) & .000 & .000 & .000 & & .000 & .000 \\
\hline & $\mathrm{N}$ & 309 & 309 & 309 & 309 & 309 & 309 \\
\hline & Pearson Correlation & $.656^{* *}$ & $.774^{* *}$ & $.817^{* *}$ & $.749^{* *}$ & 1 & $.834^{* *}$ \\
\hline \multirow[t]{3}{*}{$\mathrm{CV}$} & Sig. (2-tailed) & .000 & .000 & .000 & .000 & & .000 \\
\hline & $\mathrm{N}$ & 309 & 309 & 309 & 309 & 309 & 309 \\
\hline & Pearson Correlation & $.718^{* *}$ & $.811^{* * *}$ & $.809^{* *}$ & $.761^{* * *}$ & $.834^{* *}$ & 1 \\
\hline \multirow[t]{2}{*}{ PD } & Sig. (2-tailed) & .000 & .000 & .000 & .000 & .000 & \\
\hline & $\mathrm{N}$ & 309 & 309 & 309 & 309 & 309 & 309 \\
\hline
\end{tabular}

**. Correlation is significant at the 0.01 level (2-tailed).

$\mathrm{IU}=$ interpersonal utility, IS = information seeking, ET = entertainment, $\mathrm{PT}=$ passing time, $\mathrm{CV}=$ convenience, $\mathrm{PD}=$ purchasing decisions

According to the shaded coefficient values shown in Table 3, all five independent variables (interpersonal utility, information seeking, entertainment, passing time, and convenience) 
Volume 3 Issue 7 (March 2021) PP. 10-23 DOI 10.35631/AIJBES.37002

revealed positive and significant relationship toward purchasing decision. As per Schober et al. (2018) guideline of interpreting correlation coefficient, $r$ value in the range of 0.70 to 0.89 is considered as strong correlation. Therefore, it can be interpreted that interpersonal utility, information seeking, entertainment, passing time, and convenience have strong positive correlation with purchasing decisions.

\section{Discussion of Hypotheses}

H1: There is a positive relationship between interpersonal utility and online purchasing decisions among university students.

The first hypothesis of the study is to determine the relationship between interpersonal utility and purchasing decisions based on Facebook advertising. According to the Pearson correlation result shown in Table 3, the $r$ value of $0.811(\mathrm{p}=0.000)$ is indicating a strong and significant positive relationship between interpersonal utility and purchasing decisions. Moreover, interpersonal utility has the highest coefficient value than information seeking and entertainment.

Interpersonal utility can be very useful and effective if it is used correctly. The reason behind this positive relationship is that interpersonal utility can be referred as a feeling of satisfaction one gets from purchasing products or services, and the statistics of this interpersonal utility can be used as a tool by Facebook advertising. The finding is consistent with past studies by which also observed interpersonal utility as the most prominent impulse that triggers respondent's behavioural towards social media advertising (Celebi, 2015; Lee et al., 2016). Thus, the hypothesis is accepted.

H2: There is a positive relationship between information seeking and online purchasing decisions among university students.

The second hypothesis of the study is to determine the relationship between information seeking and purchasing decisions based on Facebook advertising. According to the Pearson correlation result shown in Table 3, the $r$ value of $0.718(\mathrm{p}=0.000)$ is indicating a strong and significant positive relationship between information seeking and purchasing decisions.

The easier the process of seeking information, the more influential it is on the consumers' purchasing decisions. This finding is consistent with past studies which claimed that consumers are able to understand more information about a product by simply going to the sellers' profile and interacting with them directly (Bomariya \& Singh, 2011), and when this process of information seeking is made easier, consumers could make their purchasing decisions even faster and with more confidence (Rathy \& Samy, 2015). This is because consumers tend to seek opinions online and share it among their social media friends, just as they do offline, which strongly affects their online purchasing decisions (Bilgihan et al., 2014). Furthermore, the act of information seeking increases familiarity with the personal seller and the sense of social presence which in turn helpful to make effective online purchasing decisions (Hajli et al., 2017). Thus, the hypothesis is accepted. 
Volume 3 Issue 7 (March 2021) PP. 10-23

DOI 10.35631/AIJBES.37002

H3: There is a positive relationship between entertainment and online purchasing decisions among university students.

The third hypothesis of the study is to determine the relationship between entertainment and purchasing decisions based on Facebook advertising. According to the Pearson correlation result shown in Table 3, the $r$ value of $0.809(\mathrm{p}=0.000)$ is indicating a strong and significant positive relationship between entertainment and purchasing decisions.

The finding is consistent with past studies which claimed that entertainment is positively associated with attitude towards purchasing decisions (Celebi, 2015; El-Ashmawy, 2014; Julianto, 2017). Abu-Ghosh et al. (2018) further highlighted that entertainment is an important variable when evaluating attitude towards Facebook advertising which able to grab the consumers' attention almost instantly. This means that entertainment is also a vital factor to enhance online purchasing decisions among consumers. Thus, the hypothesis is accepted.

H4: There is a positive relationship between passing time and online purchasing decisions among university students.

The fourth hypothesis of the study is to determine the relationship between passing time and purchasing decision based on Facebook advertising. According to the Pearson correlation result shown in Table 3, the $r$ value of $0.761(\mathrm{p}=0.000)$ is indicating a strong and significant positive relationship between passing time and purchasing decisions.

In general, when the need to pass time is strong, it means consumers spend more time on the internet due to boredom (Bednarz, 2011). Consumers' pass time motivation has a positive influence on Facebook advertising because they are spending more time on the internet. As they spend more time on the internet to pass time, there will be a higher chance of them digging through the advertisement and gain more understanding of the advertising as well. The finding is consistent with past studies which claimed that passing time is positively associated with attitude towards purchasing decisions (Chen et al., 2016; Leung, 2020; Sundstrom et al., 2019). Consumers are easily triggered by features of online shopping, hence, online shopping becomes an easy way to kill boredom. Thus, the hypothesis is accepted.

\section{H5: There is a positive relationship between convenience and online purchasing decisions among university students.}

The final hypothesis of the study is to determine the relationship between convenience and purchasing decisions based on Facebook advertising. According to the Pearson correlation result shown in Table 3, the $r$ value of $0.834(\mathrm{p}=0.000)$ is indicating a strong and significant positive relationship between convenience and purchasing decisions. It is important to note that convenience and purchasing decisions scored the highest Pearson correlation value compared to the rest of the independent variables. This indicates that convenience is the most influential factor of purchasing decisions based on Facebook advertising among the respondents.

There is a favourable relationship between convenience and consumer purchasing decisions. Solely due to the benefits such as shorter waiting time, no physical travelling and able to avoid crowds and queues; a lot of consumer has slowly adapted to shopping on Facebook (Forsythe, et al, 2006). Furthermore, according to Juniwati (2014), as Facebook offers wide variety of products from different stores, only relevant products that the specific consumer is interested in are shown to them, allowing them to quickly proceed to the specific online store to shop, 
Volume 3 Issue 7 (March 2021) PP. 10-23 DOI 10.35631/AIJBES.37002

gather information and make purchase. Therefore, there is no doubt that positive relationship between convenience and consumer purchasing decision has the highest Pearson correlation.

The finding is consistent with past studies which claimed that convenience is positively associated with attitude towards purchasing decisions (Aldousari et al., 2016; Almarashdeh et al., 2019; Duarte et al., 2018). Hence, the hypothesis is accepted.

\section{Conclusion}

The main objective of this study was to identify the relationship between interpersonal utility, information seeking, entertainment, passing time, and convenience (independent variables) and the online purchasing decisions (dependent variable) based on Facebook advertising. It was found that all five independent variables have a strong positive relationship with online purchasing decisions. It is important to highlight that convenience has the highest Pearson correlation towards purchasing decisions based on Facebook advertising.

This study discovered that interpersonal utility, information seeking, entertainment, passing time, and convenience are strongly influence university students' online purchasing decisions based on Facebook advertising posted by personal sellers. Therefore, Facebook personal sellers should pay more attention on these five factors to further improve the visibility of their Facebook business and to increase their sales growth among university students.

\section{Recommendation}

Future researchers are suggested to involve respondents from other faculties as students from one faculty do not represent the whole population of the university. Furthermore, the factors influencing students' online purchasing decision may be different with each faculty. Since the present study unable to recruit equal number of respondents from all three main ethnics in Malaysia, it is recommended for future researchers to consider involve respondents from other ethnics in equal numbers. By doing so, the effect of the independent variables toward the online purchasing decision could be analyse whether the influencing factors can be different on students from different races. Last but not least, future studies should also investigate other social media along with Facebook.

\section{References}

Abu-Ghosh, D. H., Al-Dmour, H., Alalwan, A. A., \& Al-Dmour, R. H. (2018). Factors affecting Jordanian consumers' attitudes towards Facebook advertising: Case study of tourism. In Emerging Markets from a Multidisciplinary Perspective (pp. 285-302). Springer, Cham. http://dx.doi.org/10.1007/978-3-319-75013-2_22

Agosi, M., \& Pakdeejirakul, W. (2013). Consumer selection and decision-making process. (Master thesis, Mälardalen University, Sweden). Retrieved from http://www.divaportal.org/smash/get/diva2:684213/FULLTEXT01.pdf

Ahmed, K. M. (2020). Effect of design elements for social media ads on consumer's purchasing decision. Global Media Journal, 18(34), 1-12.

Aldousari, A.A., Delafrooz, N., Ab Yajid, M.S. \& Ahmed, Z.U. (2016). Determinants of consumers' attitudes toward online shopping". Journal of Transnational Management, 21(4), 183-199. https://doi.org/10.1080/15475778.2016.1226658

Almarashdeh, I., Jaradat, G., Abuhamdah, A., Alsmadi, M., Alazzam, M. B., Alkhasawneh, R., \& Awawdeh, I. (2019). The difference between shopping online using mobile apps and website shopping: A case study of service convenience. International Journal of Computer Information Systems and Industrial Management Applications, 11, 151-160. 
Volume 3 Issue 7 (March 2021) PP. 10-23 DOI 10.35631/AIJBES.37002

Bamoriya, H., \& Singh, R. (2011). Attitude towards advertising and information seeking behavior-A structural equation modeling approach. European Journal of Business and Management, 3(3).

Bednarz, A. (2011). Why are you online? Just passing time: Using the Internet out of boredom? Not unusual. In fact, it's a common diversion these days. NetworkWorld. Retrieved April, 29, 2014 from http://www.networkworld.com/community/blog/why-are-youonline-just-passing-time

Bilgihan, A., Peng, C., \& Kandampully, J. (2014). Generation Y's dining information seeking and sharing behavior on social networking sites. International Journal of Contemporary Hospitality Management, 26(3), 349-366. https://doi.org/10.1108/IJCHM-11-2012-0220

Buzeta, C., De Pelsmacker, P., \& Dens, N. (2020). Motivations to use different social media types and their impact on consumers' online brand-related activities (COBRAs). Journal of Interactive Marketing, 52, 79-98. https://doi.org/10.1016/j.intmar.2020.04.004

Celebi, S. I. (2015). How do motives affect attitudes and behaviors toward internet advertising and Facebook advertising?. Computers in Human Behavior, 51, 312-324. https://doi.org/10.1016/j.chb.2015.05.011

Chaturvedi, S., Gupta, S., \& Singh Hada, D. (2016). Perceived risk, trust and information seeking behavior as antecedents of online apparel buying behavior in India: An exploratory study in context of Rajasthan. International Review of Management and Marketing, 6(4), 935-943. http://dx.doi.org/10.2139/ssrn.3204971

Chen, J. V., Su, B. C., \& Widjaja, A. E. (2016). Facebook C2C social commerce: A study of online impulse buying. Decision Support Systems, 83, 57-69. https://doi.org/10.1016/j.dss.2015.12.008

Eginli, A. T., \& Tas, N. O. (2018). Interpersonal communication in social networking sites: An investigation in the framework of uses and gratification theory. Online Journal of Communication and Media Technologies, 8(2), 81-104.

Elliott, M. T., \& Speck, P. S. (2005). Factors that affect attitude toward a retail web site. Journal of Marketing Theory and Practice, 13(1), 40-51. https://doi.org/10.1080/10696679.2005.11658537

El-Ashmawy, M., \& El Sahn, F. (2014). Measuring university student's attitude towards Facebook advertising. The Macrotheme Review, 3(9), 40-55.

Farah, G. A., Ahmad, M., Muqarrab, H., Turi, J. A., \& Bashir, S. (2018). Online shopping behavior among university students: Case study of Must University. Advances in Social Sciences Research Journal, 5(4) 228-242. https://doi.org/10.14738/assrj.54.4429

Forsythe, S., Liu, C., Shannon, D., \& Gardner, L. C. (2006). Development of a scale to measure the perceived benefits and risks of online shopping. Journal of Interactive Marketing, 20(2), 55-75. https://doi.org/10.1002/dir.20061

Fuchs, C. (2017). Social media: A critical introduction. London: Sage.

Haider, T., \& Shakib, S. (2018). A study on the influences of advertisement on consumer buying behavior. Business Studies Journal, 9(1).

Hajli, N., Sims, J., Zadeh, A. H., \& Richard, M. O. (2017). A social commerce investigation of the role of trust in a social networking site on purchase intentions. Journal of Business Research, 71, 133-141. https://doi.org/10.1016/j.jbusres.2016.10.004

Huang, J., \& Zhou, L. (2018). Timing of web personalization in mobile shopping: A perspective from Uses and Gratifications Theory. Computers in Human Behavior, 88, 103-113. https://doi.org/10.1016/j.chb.2018.06.035 
Volume 3 Issue 7 (March 2021) PP. 10-23 DOI 10.35631/AIJBES.37002

Hur, K., Kim, T. T., Karatepe, O. M., \& Lee, G. (2017). An exploration of the factors influencing social media continuance usage and information sharing intentions among Korean travellers. Tourism Management, 63, 170-178.

https://doi.org/10.1016/j.tourman.2017.06.013

Jamali, S. K., Samadi, B., \& Marthandan, G. (2014). Prioritizing electronic commerce technologies in Iranian family SMEs. Interdisciplinary Journal of Contemporary Research in Business, 6(2), 148-180.

Jiang, L. A., Yang, Z., \& Jun, M. (2013). Measuring consumer perceptions of online shopping convenience. Journal of Service Management, 24(2), 191-214.

https://doi.org/10.1108/09564231311323962

Julianto, R. B. (2017). The influence of Facebook advertising on purchase intention [Doctoral dissertation, President University].

http://repository.president.ac.id/xmlui/handle/123456789/1632

Juniwati, J. (2014). Influence of perceived usefulness, ease of use, risk on attitude and intention to shop online. European Journal of Business and Management, 6(27), 218-229.

Kang, J. Y. M., \& Johnson, K. K. (2015). F-Commerce platform for apparel online social shopping: Testing a Mowen's 3M model. International Journal of Information Management, 35(6), 691-701. https://doi.org/10.1016/j.ijinfomgt.2015.07.004

Karimi, L., Khodabandelou, R., Ehsani, M., \& Ahmad, M. (2014). Applying the Uses and Gratifications Theory to Compare Higher Education Students' Motivation for Using Social Networking Sites: Experiences from Iran, Malaysia, United Kingdom, and South Africa. Contemporary educational technology, 5(1), 53-72.

Kawa, A., \& Maryniak, A. (2018). "Lean and agile supply chains of e-commerce in terms of customer value creation", in Sieminski, A., Kozierkiewicz, A., Nunez, M. and Ha, Q. (Eds), Modern Approaches for Intelligent Information and Database Systems, Studies in Computational Intelligence, 769, Springer, Cham, pp. 317-327.

Kawaf, F., \& Istanbulluoglu, D. (2019). Online fashion shopping paradox: The role of customer reviews and Facebook marketing. Journal of Retailing and Consumer Services, 48, 144153. https://doi.org/10.1016/j.jretconser.2019.02.017

Kircaburun, K., Alhabash, S., Tosuntaş, Ş. B., \& Griffiths, M. D. (2020). Uses and gratifications of problematic social media use among university students: A simultaneous examination of the Big Five of personality traits, social media platforms, and social media use motives. International Journal of Mental Health and Addiction, 18(3), 525-547. https://doi.org/10.1007/s11469-018-9940-6

Kotler, P., \& Keller, K. (2011). Marketing management (14th ed.). New Jersey: Prentice Hall.

Krejcie, R. V., \& Morgan, D. W. (1970). Determining sample size for research activities. Educational and Psychological Measurement, 30(3), 607-610.

Kumar, D., \& Govindarajo, N. S. (2015). Malaysian consumer research: Does computer literacy affirmative towards e-commerce activities?. Journal of Economics and Behavioral Studies, 7(1 (J)), 50-63. https://doi.org/10.22610/jebs.v7i1(J).562

Lautiainen, T. (2015). Factors affecting consumers' buying decision in the selection of a coffee brand [Bachelor Thesis, Saimaa University of Applied Sciences]. http://urn.fi/URN:NBN:fi:amk-2015052710823

Lee, S. Y., Hansen, S. S., \& Lee, J. K. (2016). What makes us click "like" on Facebook? Examining psychological, technological, and motivational factors on virtual endorsement. Computer Communications, 33, 332-341. https://doi.org/10.1016/j.comcom.2015.08.002 
Volume 3 Issue 7 (March 2021) PP. 10-23 DOI 10.35631/AIJBES.37002

Leung, L. (2020). Exploring the relationship between smartphone activities, flow experience, and boredom in free time. Computers in Human Behavior, 103, 130-139. https://doi.org/10.1016/j.chb.2019.09.030

Liani, D. N., \& Rina, N. (2020). Motif penggunaan media sosial twitter (studi deskriptif kuantitatif pada pengikut akun Twitter@ EXOind). Cakrawala-Jurnal Humaniora, 20(1), 63-71. https://doi.org/10.31294/jc.v20i1.7747

Meskaran, F., Shanmugamm, B., \& Ismail, Z. (2014). Factors affecting on security perception in online purchase intention. Advanced Science Letters, 20(10-11), 2004-2008.

Nadeem, W., Andreini, D., Salo, J., \& Laukkanen, T. (2015). Engaging consumers online through websites and social media: A gender study of Italian Generation Y clothing consumers. International Journal of Information Management, 35(4), 432-442.

https://doi.org/10.1016/j.ijinfomgt.2015.04.008

Najmi, A., \& Ahmed, W. (2018). Assessing channel quality to measure customers' outcome in online purchasing. International Journal of Electronic Customer Relationship Management, 11(2), 179-201. https://doi.org/10.1504/IJECRM.2018.090210

Pham, Q. T., Tran, X. P., Misra, S., Maskeliūnas, R., \& Damaševičius, R. (2018). Relationship between convenience, perceived value, and repurchase intention in online shopping in Vietnam. Sustainability, 10(1), 156. https://doi.org/10.3390/su10010156

Qazzafi, S. (2019). Consumer buying decision process toward products. International Journal of Scientific Research and Engineering Development, 2 (5), 130-134.

Rathy, C., \& Samy, P. A. (2015). Advertising: Product information and consumer manipulation factors influenced Malaysian consumers buying attitude. International Journal of Business, Economics and Law, 8(2), 1-8.

Rudestam, K. E., \& Newton, R. R. (2014). Surviving your dissertation: A comprehensive guide to content and process. California: Sage Publications.

Sama, R. (2019). Impact of media advertisements on consumer behaviour. Journal of Creative Communications, 14(1), 54-68. https://doi.org/10.1177/0973258618822624

Schober, P., Boer, C., \& Schwarte, L. A. (2018). Correlation coefficients: Appropriate use and interpretation. Anesthesia \& Analgesia, 126(5), 1763-1768. https://doi.org/10.1213/ANE.0000000000002864

Soh, P. Y., Heng, H. B., Selvachandran, G., Chau, H. T. M., Abdel-Baset, M., Manogaran, G., \& Varatharajan, R. (2020). Perception, acceptance and willingness of older adults in Malaysia towards online shopping: A study using the UTAUT and IRT models. Journal of Ambient Intelligence and Humanized Computing, 1-13. https://doi.org/10.1007/s12652-020-01718-4

Statista (2020). eCommerce Malaysia. Statista. Retrieved October 15, 2020 from https://www.statista.com/outlook/243/122/ecommerce/malaysia\#market-revenue

Sundström, M., Hjelm-Lidholm, S., \& Radon, A. (2019). Clicking the boredom away Exploring impulse fashion buying behavior online. Journal of Retailing and Consumer Services, 47, 150-156. https://doi.org/10.1016/j.jretconser.2018.11.006

Tuten, T. L., \& Solomon, M. R. (2017). Social media marketing. Sage.

ur Rahman, S., Khan, M. A., \& Iqbal, N. (2018). Motivations and barriers to purchasing online: Understanding consumer responses. South Asian Journal of Business Studies, 7(1), 111128. https://doi.org/10.1108/SAJBS-11-2016-0088

Ulaan, R. V., Pangemanan, S. S., \& Lambey, L. (2016). The effect of perceived enjoyment on intention to shop online (The Study Of Faculty Of Economics And Business Sam Ratulangi University Manado). Jurnal EMBA: Jurnal Riset Ekonomi, Manajemen, Bisnis dan Akuntansi, 4(1), 1137-1145 https://doi.org/10.35794/emba.v4i1.11871 
Voorveld, H. A., van Noort, G., Muntinga, D. G., \& Bronner, F. (2018). Engagement with social media and social media advertising: The differentiating role of platform type. Journal of Advertising, 47(1), 38-54. https://doi.org/10.1080/00913367.2017.1405754

Whiting, A., \& Williams, D. (2013). Why people use social media: A uses and gratifications approach. Qualitative Market Research, 16(4), 362-369.

https://doi.org/10.1108/QMR-06-2013-0041

Zhang, H., Liang, X., \& Wang, S. (2016). Customer value anticipation, product innovativeness, and customer lifetime value: The moderating role of advertising strategy. Journal of Business Research, 69(9), 3725-3730. https://doi.org/10.1016/j.jbusres.2015.09.018

Zhang, Y., Trusov, M., Stephen, A. T., \& Jamal, Z. (2017). Online shopping and social media: Friends or foes?. Journal of Marketing, 81(6), 24-41. https://doi.org/10.1509/jm.14.0344 